\title{
MEMAHAMI DOKUMENTASI
}

\author{
Blasius Sudarsono \\ Pembelajar pada Sigma Kappa Sigma INDONESIA \\ Email:blasius@linuxmail.org
}

\begin{abstract}
In Indonesia, documentation does not develop as a science as the library. Even the documentation is forgotten or deliberately forgotten. In the United States documentation has also been considered the past since the introduction of information science. Yet it is precisely from America too, the documentation evolved into a new science. Currently there is Document Academy Meeting (DOCAM) which is held annually on an international level. At European Tromso University became the lead pioneer of documentation studies. This development seems to escape from the view of the library school in Indonesia. This paper presents a personal journey in interpreting the documentation. It is hoped that this paper can inspire librarians practitioners and academics in the field of documentation study.
\end{abstract}

Keywords: documentation, library, librarian

\section{PENDAHULUAN}

"Bertanya", minimal pada diri sendiri adalah awal dari suatu proses belajar. Apalagi memasuki dunia kerja yang masih belum pernah dikenal sebelumnya. Maka Wajar muncul pertanyaan terkait arti kata yang menjadi bagian nama lembaga yang akan menjadi tempat bekerja. Istilah atau kata itu adalah “dokumentasi”. Apakah dokumentasi,atau lengkapnya adalah "dokumentasi ilmiah"itu? Dugaan awal adalah museum ilmiah. Ternyata yang dihimpun bukan artefak, namun pustaka. Kemudian muncul pertanyaan berikutnya: "Apa beda dokumentasi dan perpustakaan?"

Sayang waktu itu belum diperoleh jawab yang memuaskan tentang dua lembaga yang sering disamakan, namun juga tidak jarang dipertentangkan. Kegiatan rutin ternyata tidak memberi banyak waktu untuk belajar, sehingga proses pembelajaran dan pencarian itu tertunda.

Upaya pencarian kembali muncul setelah "satu setengah dasa-warsa" berlalu. Dipicu pernyataan bahwa pemahaman dokumentasi tidak terbatas hanya pada dokumentasi yang biasa dianut oleh pustakawan. Dengan kata lain harus ada 
teori, konsep, atau kaidah mendasar dari dokumentasi yang berlaku secara umum. Namun "tidak banyak", untuk mengatakan "tidak ada" yang tertarik mendiskusikan masalah dokumentasi.Ada anggapan bahwa dokumentasi adalah masa lalu, dan sekarang sudah diganti dengan ilmu atau sistem informasi. Pengaruh Amerika Serikat yang menjadikan American Documentation Institute (ADI) menjadi American Society for Information Science (ASIS) sangat besar. Dokumentasi ditinggalkan karena yakin bahwa yang terbaru adalah Ilmu Informasi. Keyakinan mengenai ilmu informasi itu juga mendominasi para cerdikpandai di bidang perpustakaan dan kepustakawanan Indonesia.

Meskidokumentasi di Amerika Serikat telah ditinggalkan, namun pada awal milenium ketiga dari Amerika jugalah muncul ide tentang pembelajaran kembali konsep dokumentasi Eropa yang lahir sejak akhir abad 19. Kerjasama Universitas California di Berkeley dan Universitas Tromso di Norwegia melahirkanDocument Academy yang menyelenggarakan pertemuan tahunan: Documentation Academy Meeting (DOCAM) sejak 2003 sampai sekarang. Dari seri pertemuan itulah lahir konsep dan teori baru tentang dokumentasi. Tulisan ini menyampaikan upaya pencarian dan pembelajaran tentang makna dokumentasi. Selain itu dimaksudkan untuk mengenalkan konsep baru dokumentasi. Diharapkan terjadi diskusi berkesinambungan sehingga pada saatnya nanti ilmu dokumentasi baru menjadi salah satu mata kuliah, dan konsorsium ilmu dokumentasi nantinya dapat terwujud di Indonesia. Referensi utama tulisan ini adalah buku: Menuju Era Baru Dokumentasi (MEBD). Jakarta: LIPI Press, 2016. Kutipan SENGAJA diambil dari buku tersebut, untuk mengingatkanagar buku itu dibaca lagi. Buku tersebut perlu dijabarkan dengan lebih rinci.Diharapkan semakin banyak pihak yang berminat pada dokumentasi.

\section{PEMBAHASAN}

\section{Perjalanan Dokumentasi}

Dalam keseharian hidup kita, tentu pernah mendengar atau mengucapkan kata dokumentasi. Arti dan makna dokumentasi tentu sangat beragam, tidak terbatas hanya pada pengertian yang biasa dimaksud oleh kalangan pustakawan. Di Indonesia, pustakawan sering mengucapkannya bersamaan dengan kata 
perpustakaan dan informasi menjadi "perpustakaan, dokumentasi, dan informasi”. Untuk singkatnya muncul akronim "pusdokinfo".Akronim ini biasa diucapkan dalam satu tarikan nafas, sehingga memberi kesan penyamaan arti tiga kata yang lebih berpusat pada perpustakaan.Selanjutnya dengan lebih populernya kata “informasi”, terjadi pergeseran fokus dariperpustakaan ke“informasi”. Bahkan pustakawan mulai menyebutdirinya juga sebagai ahli informasi. Ilmu yang menjadidasar pemikiran dan tindakan juga bergeserdari ilmu perpustakaan ke ilmu informasi. Lalu bagaimana dengan nasib dari kata dokumentasi?

Sebenarnya sudah diterbitkan Peraturan Presiden Republik Indonesia Nomor 20 Tahun 1961 (Per-Pres No. 20, 1961) tentang Tugas-Kewajiban dan Lapangan Pekerjaan Dokumentasi dan Perpustakaan dalam Lingkungan Pemerintahan. Yang dimaksud dokumentasi dalam peraturan ini adalah dokumentasi pustaka (literair), tidak termasuk dokumentasi benda (corporeel) atau non-pustaka, yaitu yang termasuk bahan-bahan dokumentasi museum dan gudang. Tidak ada definisi jelas dari "dokumen pustaka" dalam peraturan itu. Hanya dimaksudkan tiap benda yang berwujud tulisan tercetak, difotokopi atau direkam dan yang dapat memberikan keterangan tentang pengetahuan dalam arti yang luas sebagai kegiatan manusia. Begitu banyak kegiatan manusia, begitu banyak kegiatan dokumentasi pustaka maupun non-pustaka yang terkait. Semua ini tentu memerlukan landasan keilmuan yang kuat tentang dokumentasi.

Semula sudah ada organisasi profesi yang menghimpun pustakawan, arsiparis dan dokumentalis. Dibentuk pada tahun 1956,bernama Perhimpunan Ahli Perpustakaan, Arsip, dan Dokumentasi Indonesia (PAPADI). Pada tahun 1962 PAPADI berubah menjadi Asosiasi Perpustakaan Arsip dan Dokumentasi Indonesia (APADI). Kemudian pada 1969 lahir Himpunan Pustakawan Chusus Indonesia (HPCI). Anggota HPCI adalah para pustakawan khusus yang sering menyebut dirinya sebagai “dokumentalis". Pada tahun 1973 lahir Ikatan Pustakawan Indonesia (IPI) yang adalah leburan dari APADI, HPCI, dan Perhimpunan Perpustakaan Daerah Istimewa Yogyakarta (PPDIY). Pengembangan profesi memang menjadi tanggung jawab utama dari organisasi profesi. Tidak disadari, dengan nama organisasi yang sebelumnya menghimpun tiga profesi yaitu pustakawan, arsiparis, dan dokumentalis kemudian hanya 
mewadahi profesi pustakawan saja. Bagaimana dengan pengembangan dua profesi lainnya?

Tentang arsiparis, mungkin ada anggapan bahwa arsiparis akan berhimpun dalam satu organisasi khusus dengan lahirnya Undang-Undang Pokok Kearsipan tahun 1971. Kenyataannya organisasi khusus arsiparis baru muncul sekitar 2008 dengan lahirnya Undang-Undang Kearsipan yang baru sebagai revisi UU kearsipan 1971. Yang tidak pernah muncul adalah organisasi terkait dokumentasi. Bahkan terminologi dokumentasi terlupakan atau memang dilupakan karena sudah dianggap masa lampau karena sudah digantikan dengan kata "informasi". Di pihak lain, pribadi yang waktu itu menyebut dirinya “dokumentalis" sepertinya juga tidak punya ambisi untuk membangun dan mengembangkan ilmu dokumentasi. Keadaan itu saya sebut sebagai dokumentasi yang terlupakan (Sudarsono, 2016, hal. 85-102).

Keterlupaan dokumentasi tidak hanya terjadi di Indonesia. Di Amerika Serikat dokumentasi juga dilupakan atau ditinggalkan dengan berubahnya nama American Documentation Institute (ADI) menjadi American Society for Information Science (ASIS), kemudian menjadi American Society of Information Science and Technology (ASIST), dan akhirnya pada 2013 menjadi Association for Information Science and Technology (ASIS\&T). Dokumentasi kemudian digantikan dengan ilmu informasi. Tidak heran adanya pendapat bahwa dokumentasi sudah ketinggalan jaman. Pendapat ini juga dianut oleh mayoritas cerdik pandai kepustakawanan kita. Tidak pernah diduga bahwa kesadaran tentang dokumentasi antara lain justru muncul dari Amerika Serikat. Pada tahun 1987 Michael Keeble Buckland, seorang professor di sekolah perpustakaan University of California, Berkeley dan juga presiden dari ASIST, terheran-heran dengan koleksi "bangkai burung" yang disimpan dalam koleksi museum ornitologi di kampusnya.

Dia mempertanyakan mengapa "bangkai burung" itu disimpan di "lokasi termahal" kampusnya. Setelah mendapat penjelasan, dia berpendapat bahwa fungsi "bangkai burung" itu seperti juga koleksi buku dalam perpustakaan. Sayang dia belum menemukan referensi yang mendukung pendapatnya.Barulah dia sadar saat membaca tulisan Suzanne Briet berjudul: Qu'est-ce que la 
documentation?(Apakah Dokumentasi itu) yang diterima dari Warden Boyd Rayward pada 1998.

Buckland sadar bahwa konsep yang saat itu dipikirkannya ternyata telah ditulis oleh Briet hampir 40 tahun sebelumnya. Buckland kemudian mempelajari karya Briet dan para pendahulunya seperti Paul Otlet, Henri La Fontaine, Emanuel Goldberg, dan tokoh gerakan awal dokumentasi di Eropa lainnya. Di ASIST sendiri kemudian dibentuk kelompok yang mempelajari sejarah informasi dan menerjemahkan karya Eropa ke bahasa Inggris.

Tokoh ketiga dalam gerakan dokumentalis baru adalah Niels Windfeld Lund dari Norwegia. Pada 1989 Undang-Undang Deposit yang baru terbit di Norwegia yang mengatakan bahwa semua jenis publikasi dalam format apa saja, termasuk dokumen online harus didepoditkan. Untuk menjawab kriteria deposit itu, otoritas Norwegia di Trompso menggunakan istilah dokumen dan bukan informasi. Sejalan dengan itu Lund membangun sekolah perpustakaan baru di University of Tromso dengan nama Documentation Studies. Terminologi dokumen dimaksudkan sebagai inti konsep yang mengacu pada semua benda yang berpotensi menerangkan. Dokumentasi dipahami sebagai proses dan produk. Studi dokumentasi mencakup tiga dimensi yang saling melengkapi, yaitu 1) aspek kognitif, 2) aspek teknologi, dan 3) aspek sosial. Dengan sendirinya pengajar pada program studi itu juga meliputi para ahli dalam bidang kemanusiaan (humanities), ilmuwan ilmu sosial (social scientists), dan para ahli komputer (computer scientists).

Buckland, Lund, dan Rayward selanjutnya menjadi pioneer gerakan dokumentasi baru. Kata Rayward dan Buckland diucapkan untuk Lund tentang sekolah dokumentasinya: "You have history with you and together we present the neo-documentalist movement". Selanjutnya dibangun Document Academy (Dokumen Akademi) yang merupakan kerjasama antara University of California di Berkeley dan University of Tromso. Pertemuan tahunan Document Academy Meeting (DOCAM) diselenggarakan sejak 2003 sampai sekarang. Dalam DOCAM dibahas objek intinya yaitu dokumen (dokumen sebagai pusat studi) yang dilihat secara menyeluruh dari berbagai aspek secara komprehensif. Gerakan 
dokumentalis baru inilah yang telah menghasilkan "ilmu dokumentasi" baru atau "teori umum dokumen(tasi)" (Sudarsono, 2016, hal. 103-117).

Harus diterangkan di sini adanya fenomena lain, yang meski tidak secara langsung terjadi karena adanya gerakan dokumentalis baru, namun sangat erat kaitannya dengan "konsep baru" tentang dokumen. Fenomena tersebut adalah mengerucutnya pandangan tentang lembaga dokumenter.Konvergensi atas fungsi perpustakaan, lembaga arsip, dan museum di lingkup dunia internasional semakin cepat bergerak semenjak bergesernya koleksi fisik menjadi koleksi digital. Rayward termasuk akademisi pertama yang memikirkan konvergensi sejak 1996.Namun baru pada 2004 konvergensi menjadi kenyataan dengan disatukannya Perpustakaan Nasional Kanada dan Arsip Nasional Kanada menjadi Library and Archive of Canada (LAC). Pemikiran ide konvergensi di Amerika Serikat juga baru diawali pada 2005. Memang Rayward cukup tajam analisis keilmuannya tentang prospek dunia yang semakin mendigital.

Sumberdaya yang ada dalam perpustakaan, arsip, dan museum mengalami digitalisasi atau memang terlahir sudah digital. Semua itu menjadi lebih mudah terakses melalui jaringan global. Pengguna tidak perlu tahu di mana sebenarnya informasi atau pengetahuan yang dicari itu berada atau dari mana asalnya. Pustakawan, arsiparis, muesolog, atau profesional dokumentasi lainnya yang menyiapkan semua itu agar dapat diakses melalui internet. Harus diakui bahwa konvergensi dalam hal ini terutama adalah konvergensi fungsi berbagai lembaga dokumenter, dan tidak selalu konvergensi fisik lembaga. Harus diakui betapa sulitnya untuk menggabungkan arsip dan perpustakaan secara fisik lembaganya. Memang tidak harus menjadi satu. Namun menjadi keniscayaan adalah konvergensi atas fungsi lembaga dokumenter. Diperlukan kesamaan pemahaman atas “dokumen”. Dalam hal inilah peran ilmu dokumen(tasi) baru menjadi vital.

\section{Perkembangan Baru Dokumentasi}

Seperti diketahui, dokumentasi dilahirkan oleh dua bersahabat Paul Otlet dan Henri La Fontaine pada 1895. Kerisauan mereka dipicu dengan meledaknya publikasi ilmiah sehubungan dipakainya mesin cetak. Mereka berpendapat dan berupaya membangun sistem yang mengumpulkan, mengorganisasikan informasi 
terbitan ilmiah dan menyediakannya untuk keperluan masyarakat ilmiah. Kegiatan dan sistem yang dihasilkan itulah yang dinamakan dokumentasi. Wajar saja jika Kamus Besar Bahasa Indonesia (daring) mengartikan dokumentasi adalah:

a. pengumpulan, pemilihan, pengolahan, dan penyimpanan informasi dalam bidang pengetahuan; dan

b. pemberian atau pengumpulan bukti dan keterangan (seperti gambar, kutipan, guntingan koran, dan bahan referensi lain).

Kegiatan dokumentasi ini memang ada tumpang tindihnya dengan kegiatan perpustakaan. Tidak heran pihak yang pro perpustakaan mengatakan bahwa dokumentasi adalah bagian dari kegiatan perpustakaan. Di sisi lain mengatakan bahwa perpustakaan adalah salah satu hasil dokumentasi. Sebenarnya yang membedakan antara perpustakaan dan dokumentasi adalah objek kerjanya. Objek kerja perpustakaan adalah buku atau pustaka. Sedang objek kerja dokumentasi adalah dokumen. Maka Wajar jika muncul pertanyaan: "Apa sebenarnya dokumen itu?'Pendapat Paul Otlet mengatakan bahwa dokumen adalah benda tiga dimensi mati. Dokumen tercetak adalah juga benda tiga dimensi mati meski ketebalannya sangat tipis. Sehingga ada yang berpendapat dokumen menurut Otlet adalah dua dan tiga dimensi mati.Briet menambahkan bahwa dokumen juga bisa berupa tiga dimensi hidup (kasus antelope).

Pendapat lain tentang dokumen datang dari Donker Duyvis. Tidak hanya memandang dari sisi fisik atau materi saja, Donker memandang juga dari sisi spiritual. Donker memaknai dokumen sebagai ekspresi pikiran manusia sesuai pendapat Otlet. Ranganathan dari India mempunyai pemaknaan lain tentang dokumen. Dikatakan bahwa dokumen adalah Microthought on a flat surface. Namun Ranganathan menolak memasukkan materi audiovisual, radio, dan komunikasi melalui televise sebagai dokumen. Dia yakin bahwa dokumen bersinonim dengan hasil pikir yang terekam di kertas, yang dapat dipegang secara fisik, dan dapat dilestarikan sepanjang masa. Di Amerika Serikat, Louis Shore mengatakan bahwa dokumen adalah rekaman tekstual, yang dapat mencakup komunikasi audiovisual yang dinamakan the generic book. Jesse H. Shera menyebut apa yang dimaksud Louis Shore dengan the graphic record. 
Penelusuran Lund akan makna dokumentasi berawal dari arti kata itu dalam kamus kuno Bahasa Perancis. Mulanya adalah dari kata Latin documentum. Arti kata ini dalam Bahasa Latin terkait dengan: contoh, model, pelajaran, mengajar dan menunjukkan. Dapat disimpulkan bahwa pelajaran yang disampaikan secara lisan adalah sejenis dokumen juga. Namun arti dan makna ini, kini sudah agak terlupakan. Kini selain dilihat sifat bibliografisnya, dokumen biasa terkait dengan sifat hukum dan ilmiah. Dokumen adalah sesuatu yang mendukung fakta dengan bukti tertulis. Dalam sejarahnya, pengadilan selalu memutuskan perkara berdasar dengan adanya bukti tertulis ini. Demikian juga dalam lingkup ilmiah. Ilmuwan menulis apa yang ditemukan dengan artikel ilmiah. Siapa yang lebih dahulu menulis dokumen ilmiah adalah yang berhak atas penemuan baru itu. Secara singkat dokumen pada dasarnya adalah objek tertulis. Kedua, dokumen adalah bukti, dan ketiga dokumen adalah pembawa informasi.

Terkait dengan era digital, bahwa dunia semakin mendigital, Lund mempertanyakan di manakah sebenarnya dokumen yang kita buat dengan program pengolah kata itu? Tidak ada wujud fisik dokumen, kecuali kita membuatnya tercetak. Hal ini berlawanan dengan konsep dokumen konvensional. Lund berpendapat bahwa dalam situasi digital dokumen adalah konsep satuan yang diskrit (dalam hal ini disebut "bit"), yang diperlukan orang untuk dibaca, dilihat, atau didengar. Oleh karena itu dokumen tidak perlu harus berwujud objek fisik yang tetap. Kembali pada arti kata dokumen pada masa dahulu, yang menerima makna dokumen sebagai pelajaran, maka ujaran maupun bahasa tubuh adalah juga dokumen. Lund mendefinisikan dokumen adalah:

hasil upaya manusia untuk mengatakan, menginstruksikan, meragakan, mengajar, atau mengadakan pertunjukan, secara singkat mendokumentasikan dengan memakai alat dan cara tertentu. Konsep Lund ini dapat menjadi sangat luas. Hampir semua bisa dianggap dokumen. Namun pada saat tertentu bisa sangat khusus. Saya cenderung mengatakan: Semua yang melaksanakan fungsi dokumen adalah juga dokumen. (BS, 2016).

Lebih lanjut Buckland mengatakan bahwa budaya dan masyarakat hidup dan berkembang melalui komunikasi dan kolaborasi. Sayang bahwa kita sudah tidak mudah melakukannya secara langsung karena berbagai kendala ruang dan 
waktu. Bahkan mungkin pihak lain sudah mati. Jalan terbaik kita kembali pada dokumen. Apakah yang pernah dikatakan, dilakukan, atau ditulis oleh atau tentang orang yang kita maksud termasuk ide dan pemikirannya? Dokumen menjadi perekat masyarakat terutama karena potensinya dalam memantau, mempengaruhi, dan melakukan negosiasi serta relasi antar manusia. Kita sekarang hidup dalam masyarakat dokumen seperti yang dinyatakan Buckland. Sehingga jika pada awalnya manusia berangkat dari kelisanan (orality) kemudian berkembang dengan keberaksaraan (literacy), sekarang dalam masyarakat dokumen (document society). Keberadaan "kaki" ketiga yaitu documentality (dokumentalitas).

Theory of Documentality (teori dokumentalitas) dirumuskan oleh Maurizio Ferraris sejak 2005. Dia mengembangkan teori bertolak dari rumusan seorang filosof Amerika Serikat, John Searle tentang "a huge invisible ontology", atau the ontology of social objects(1995). Untuk menerangkan "objek sosial" Searle merumuskan hukum: " $X$ counts as $Y$ in $C$ ". Dia mengatakan bahwa objek sosial adalah objek di atas objek fisik. Dijelaskan bahwa "dalam konteks (kondisi) C objek fisik X adalah objek sosial Y”. Faktor terpenting dalam mewujudkan realitas sosial (social reality) dinamai Searle dengan terminology "collective intentionality". Rumusan Searle inilah yang dikoreksi oleh Ferraris dengan merumuskan hukum: "Object $=$ Written Act" (2005).

Ferraris membedakan objek menjadi tiga kelompok yaitu objek fisik, objek sosial dan objek ide. Jika Searle mengatakan bahwa objek sosial berkembang dari objek fisik, Ferraris berpendapat bahwa objek sosial adalah tindakan sosial yang melibatkan minimal dua orang dicirikan dengan ditulis: pada kertas, file komputer, atau meski hanya dalam benak manusia. Menurut Ferraris, tidak ada masyarakat tanpa tulisan atau inskripsi meski hanya dalam benak manusia. Inilah teori "documentality" atau dokumentalitas. Ketergantungan realitas sosial pada dokumen inilah yang disebut dokumentalitas. Dapat juga disebut sebagai "kekuatan dokumen" atau the power of document. Maka ungkapan Derida: "There is nothing outside of the text" diubah Ferraris menjadi "There is nothing social outside of the text". 
Sampai di sini sudah terlihat jelas begitu luasnya cakupan ilmu dokumentasi. Dapat dimengerti juga bahwa yang selama ini dibahas dalam "perkuliahan dokumentasi" belum mencakup semua hal tersebut.Perkembangan internasional sejak 2003 mungkin belum diikuti karena dapat diduga perhatian pada hal-hal teknis lebih mendominasi. Bahkan ada kalangan yang mengatakan dokumentasi hanyalah praktik teknologis yang menempel pada bidang yang memerlukannya. Tiap bidang mempunyai penafsiran dan teknis masing-masing.Karena begitu luas cakupan ilmu dokumentasi baru, maka perlu pembelajaran berkesinambungan oleh para peminat bidang ini. Mereka idealnya dapat bertemu mendiskusikan bersama dalam forum yang diselenggarakan secara berjelanjutan juga. Sebagai penutup tulisan ini, dikutip lengkap bagaimana saya memaknai dokumentasi seperti saya sampaikan dalam buku MEBD saya. Semua yang tertulis di sini adalah pemikiran pribadi yang masih perlu ditanggapi apakah sebagai justifikasi atau falsifikasi.

\section{Memaknai Dokumentasi}

Pada bagian ini disampaikan salah satu pemikiran untuk menemukan makna dari dokumentasi. Memaknai dokumentasi didekati dengan melihat makna kata kunci pada kalimat berikut:

pada awal mula adalah hasrat (kehendak) manusia untuk mengekspresikan apa yang dirasakan dan/atau yang dipikirkannya

Kalimat di atas semula digunakan sebagai upaya pendekatan untuk memahami kepustakawanan (Sudarsono, Blasius. Dalam Kepustakawanan Indonesia: potensi dan tantangan. Jakarta: Kesaint Blanc, 1992. Hal. 149 - 160). Pada perjalanan waktu, akhirnya kalimat itulah yang digunakan dalam upaya memaknai dokumentasi melalui proses logika berpikir. Selain itu juga dilihat dari makna kata dokumentasi yang berarti baik produk maupun proses. Sehingga dijunakan tiga pendekatan: 1) makna menurut kata kunci, 2) makna dokumentasi sebagai produk, dan 3) makna dokumentasi sebagai proses.

Pada kalimat tersebut di atas dapat ditentukan kata kunci berikut (dalam huruf tebal) 
Pada awal mula adalah kehendak manusia untuk mengekspresikan apa yang dirasakan dan/atau yang dipikirkan-nya.

\section{Penjabaran Kata Kunci}

a. Awal Mula

Menyatakan awal tindakan atau apa yang dikerjakan manusia. Apabila digunakan system referensi umum dalam pernyataan fungsi $(\mathrm{x}, \mathrm{y}, \mathrm{z}, \mathrm{t})$, maka nilai " $t$ " pada Awal Mula ini adalah sama dengan nol $(\mathrm{t}=0)$.

b. Kehendak Manusia

Kata kunci ini mengandung makna "sengaja" atau "aktif". Bukan tindakan tanpa maksud, maka memang suatu tindakan yang dikehendaki. Suatu tindakan "sadar", bukannya tidak sadar. Dalam kehendak ini manusia menyatakan keberadaan atau eksistensinya. Dalam bahasa filsafati dapat dikatakan bahwa manusia "mengada"

\section{c. Mengekspresikan}

Padan kata ekspresi menurut Eko Endarmoko (2007) adalah: cetusan, luapan, pernyataan, ungkapan, air/seri muka, roman muka, rona, rupa, tampang.

Kamus besar Bahasa Indonesia (1983) menerangkan arti ekspresi adalah: 1) pengungkapan atau proses menyatakan (yaitu memperlihatkan atau menyatakan maksud, gagasan, perasaan dsb.). 2) pandangan air muka yang memperlihatkan perasaan seseorang.

Lebih lanjut arti kata mengekspresikan adalah: mengungkapkan (gagasan, maksud, perasaan, dsb) dengan gerak anggota badan, air muka, kata-kata, dsb.

Dari batasan di atas, dalam ruang lingkup mengekspresikan terlibat dua pihak yaitu pihak yang melakukan (bisa tunggal maupun jamak) dan pihak yang dituju (bisa tunggal maupun jamak). Juga sudah disebut cara atau teknik menyampaikan ekspresi tersebut seperti dengan kata-kata, gerak anggota badan, air muka, dsb (bahasa tubuh).

Selain itu yang penting adalah posisi baik pihak pertama maupun posisi pihak kedua yang dapat dinotifikasikan dalam pernyataan fungsi $(\mathrm{x}, \mathrm{y}, \mathrm{z}, \mathrm{t})$. Posisi 
pihak pertama kita sebut $\left(\mathrm{x}_{1}, \mathrm{y}_{1}, \mathrm{z}_{1}, \mathrm{t}_{1}\right)$ sedang posisi pihak kedua adalah $\left(\mathrm{x}_{2}\right.$, $\mathrm{y}_{2}, \mathrm{z}_{2}, \mathrm{t}_{2}$ ), maka dapat terjadi beberapa kemungkinan:

1) Jika $x_{1}=x_{2}, y_{1}=y_{2}, z_{1}=z_{2}, t_{1}=t_{2}$, maka akan terjadi ekspresi langsung (dengan suara maupun bahasa tubuh).

2) Jika nilai $\mathrm{x}_{1}, \mathrm{y}_{1}, \mathrm{z}_{1}$ dan $\mathrm{x}_{2}, \mathrm{y}_{2}, \mathrm{z}_{2}$ berbeda-beda, namun $\mathrm{t}_{1}$ dan $\mathrm{t}_{2}$ sama, maka tetap dapat dilakukan ekspresi langsung dengan pertolongan peralatan teknologi informasi dan komunikasi (TIK).

3) Jika nilai $x_{1}, y_{1}, z_{1}, t_{1}$ dan $x_{2}, y_{2}, z_{2}, t_{2}$ berbeda-beda, maka diperlukan upaya menyimpan sementara apa yang akan diekspresikan itu sampai kondisi butir 1) atau 2) terpenuhi agar terjadi ekspresi langsung.

4) Kondisi sementara itu untuk waktu yang tak berhingga atau $t=\infty$ dikatakan abadi

5) Maka dapat dikatakan bahwa proses dokumentasi sesungguhnya adalah proses mengabadikan.

Kata mengabadikan sudah dikenal masyarakat luas, khususnya dalam arti mengambil foto. Yang belum disebut dalam padan kata dalam Tesaurus Bahasa Indonesia, maupun makna dari KBBI adalah produk dari ekspresi tersebut. Jika disepakati bahwa dokumentasi adalah proses maupun produk, maka dokumentasi sebagai produk tentu dapat juga disebut sebagai "dokumen".

\section{d.Dirasakan}

Apa yang dirasakan dapat dibedakan dalam arti dirasakan melalui indrawi dan dirasakan melalui bukan (non) indrawi. Indrawi; a) Dilihat: pemandangan, (video); b) Didengar: suara (audio); c) Dicium (aroma); d) Dicecap (rasa); e) Diraba Objek yang dapat dirasakan dengan indrawi dikatakan dan biasanya juga objek yang terukur (kuantitatif).

Non-Inderawi; Objek yang hanya dirasakan secara non indrawi seperti perasaan hati atau suasana hati pada dasarnya adalah objek kualitatif, hanya dapat didekati dengan indikator yang bisa sedikit memberi gambaran secara kuantitatif.

e. Dipikirkan 
Objek yang dipikirkan dapat bersifat: Abstrak, imajiner, khayali, maya, mujarad, niskala, tan wujud, visioner, hipotesis, ideal, konseptual, teoritis, dan transendental

Selanjutnya tulisan ini melihat dokumentasi dari tiga sudut padang.

1. Dokumentasi Sebagai Proses

a. Manusia sebagai subjek mempunyai hasrat atau kehendak untuk mengutarakan pikiran dan/atau perasaannya. Kepada siapa? Tentu kepada sesama manusia bukan? Sesama manusia ini bisa tunggal maupun jamak. Apakah sesama manusia itu berada di dekatnya? Jika sesama manusia itu berada berdekatan, maka ekspresi itu bisa diwujudkan dengan komunikasi langsung, baik verbal maupun non-verbal.

b. Objek yang dikomunikasikan tentunya adalah apa yang dirasakan dan/atau yang dipikirkannya. Dengan kata lain komunikasi akan terjadi jika dua pihak itu, komunikator dan komunikan berada dalam ruang yang sama dan juga pada waktu yang sama.

c. Apakah komunikasi mensyaratkan keberadaan pada ruang dan waktu yang sama? Tidak selalu! Dalam dunia yang semakin modern ini, meskipun komunikator dan komunikan tidak berada pada ruang yang sama, namun apabila tetap dalam keberadaan waktu yang sama, maka komunikasi tetap dapat dilakukan dengan bantuan teknologi komunikasi yang kemudian biasa disebut juga telekomunikasi.

d. Bagaimana jika keberadaan komunikator dan komunikan tidak pada ruang dan waktu yang sama? Jelas akan terjadi penundaan komunikasi langsung itu. Oleh karena agar apa yang dirasakan dan/atau yang dipikirkannya itu tidak terlupakan, maka diperlukan sarana pengingat atau penyimpanan sementara.

e. Selanjutnya pada saat keberadaan komunikator dan komunikan kemudian berada pada tempat dan waktu yang sama, maka komunikasi langsung dapat dilakukan dengan menyampaikan apa yang untuk sementara tadi disimpan.

f. Sarana pengingat atau penyimpanan sementara ini ada dua jenis, yaitu yang alamiah dan yang buatan. 
g. Sarana pengingat atau penyimpanan sementara yang alamiah adalah otak. Dengan otaknya, manusia mengingat apa yang akan dikomunikasikan. Otak adalah pusat ingatan manusia.

h. Sarana pengingat atau penyimpanan buatan dapat diwujudkan dengan berbagai cara mulai dari membuat tanda dalam bentuk guratan pada dinding gua, pohon, sampai dengan yang begitu canggih dalam wujud alat perekam sesuai perkembangan teknologi. Dengan kata lain manusia memerlukan cara dan sarana untuk menyimpan atau merekam sementara atas apa yang dirasakan dan/atau yang dipikirkannya.

i. Jika kita melihat jauh ke depan, maka rentang waktu sementara itu menuju ke masa "abadi". Dalam bahasa matematika kita kenal dengan masa dari $0 \rightarrow \infty$. Bertolak dari pola pikir ini saya memakai kata mengabadikan untuk menerangkan makna dokumentasi. Karena itu pada dasarnya kegiatan (proses) dokumentasi atau disebut kata turunannya yaitu mendokumentasikan adalah pengabadian atau mengabadikan.

j. Dokumentasi sebagai proses, secara umum dapat dikatakan:

1) Pada dasarnya adalah proses siklus. Objek maya didokumentasikan menjadi objek nyata atau digital. Objek nyata didokumentasikan kembali dokumen nyata lain atau digital (menggunakan TIK). Proses ini berulangulang.

2) Kegiatan mengeksplisitkan pengetahuan taksit dan mengelola pengetahuan eksplisit.

3) Langkah dalam penciptaan pengetahuan dan ilmu.

4) Simulasi kerja otak.

5) Fungsi yang harus dilakukan oleh semua orang.

2. Dokumentasi Sebagai Produk atau Objek

a. Apa yang dirasakan dan/atau dipikirkan merupakan objek ekspresi manusia. Dengan kata lain dapat dikatakan juga, apa yang dirasakan dan/atau dipikirkan adalah objek dokumentasi.

b. Apa yang dirasakan, dapat dibedakan atas yang dirasakan secara inderawi dan yang dirasakan secara non-inderawi (perasaan hati). Jadi jika ditilik dari 
wujudnya, apa yang dirasakan itu selalu ada yang dapat dilihat dan diraba atau nyata (tangible atau real), serta yang tak dapat dilihat atau diraba (intangible atau virtual).

c. Di sisi lain, menyangkut objek yang dipikirkan selalu dalam wujud tidak dapat dilihat atau diraba.

d. Dengan demikian terdapat dua objek dokumentasi, yaitu yang nyata (real, tangible) dan yang maya (virtual, intangible).

e. Objek virtual dapat berada pada dua lokasi. Yang pertama ada dalam diri manusia. Sedang lokasi kedua adalah jika objek itu tidak berada dalam diri manusia.

f. Objek virtual yang berada dalam diri manusia ada dalam pikiran dan perasaan manusia.

g. Objek dokumentasi virtual yang tidak berada dalam diri manusia, biasanya ada dalam komputer yang saat ini mayoritas tersimpan dalam bentuk digital. Kita namakan saja objek digital.

h. Dengan demikian kita kenal tiga objek dokumentasi yaitu: 1) Objek Nyata; 2) Objek Maya; dan 3) Objek Digital.

i. Objek dokumentasi dapat pula disebut dengan kata lain adalah dokumen. Dengan demikian dikenal 1) dokumen nyata; 2) dokumen maya; 3) dokument digital.

j. Objek dokumentasi (dokumen) nyata dapat berwujud dua dimensi dan tiga dimensi (Paul Otlet, 1934). Artefak dalam museum adalah dokumen.

k. Objek dokumentasi (dokumen) tiga dimensi dapat dalam status mati dan status hidup (Suzanne Briet, 1951).Binatang yang dipelihara untuk tujuan khusus adalah dokumen.

1. Objek dokumentasi (dokumen) tiga dimensi dan hidup dapat menciptakan dokumen baru non benda, dalam gerak tubuh atau bahasa tubuh (Niels Windfeld Lund, 2003).

m. Objek dokumentasi (dokumen) selalu dan akan selalu bertambah dan bahkan dapat dikatakan "meledak" seiring dengan perkembangan kehidupan manusia. 
n. Maka menjadi sangat jelas diperlukan cara untuk menyimpan informasi tentang semua dokumen yang ada, dan dilengkapi juga dengan cara menemukan kembali secara cepat saat dokumen itu diperlukan.

o. jawab atas semua keperluan tersebut adalah suatu Sistem Simpan dan Temu Kembali Informasi (SSTKI). (Sudarsono, 1992).

p. Selain sistem simpan dan temu kembali untuk informasi (deskripsi) tentang dokumen, diperlukan juga cara menyimpan koleksi dokumen secara fisik maupun digital.

q. Dalam hal ini diperlukan Sistem Simpan dan Tata Kelola Koleksi Dokumen (SSTKKD) baik yang nyata maupun yang maya (digital).

r. SSTKI dan SSTKKD dibangun dan dikembangkan dengan menerapkan teknik dan teknologi yang sesuai.

\section{Dokumentasi sebagai Ilmu}

a. Gerakan dokumentalis baru (neo-documentalist) telah berhasil menjadikan ilmu dokumentasi bangkit kembali, bahkan muncul teori atau konsep baru yang sebelumnya tidak pernah ada. Hal ini dapat dipahami karena ilmu "dokumentasi baru" meletakkan dokumen sebagai fokus studi. Dokumen sebagai objek diletakkan di pusat dan ditinjau serta dipelajari secara komprehensif dari berbagai arah dengan menerapkan berbagai disiplin keilmuan.

b. Pengertian dokumen juga menjadi semakin luas. Jika waktu awal lahir dokumentasi hanya membatasi pada objek dokumen dua dan tiga dimensi yang mati, kemudian ditambahkan dan mencakup juga objek tiga dimensi hidup. Dengan gerakan dokumentasi baru, yang dimaksud dengan dokumen sudah tidak hanya terbatas pada fisik dokumen, namun juga meliputi semua yang berpotensi dan dianggap sebagai dokumen meski dalam bentuk maya (virtual) sekalipun. Semuanya adalah dokumen jika memilliki atau melaksanakan fungsi dokumen.

c. Ilmu dokumentasi, kini adalah ilmu yang objek garapnya adalah dokumentasi. Inti utama atau mendasar dari Dokumentasi adalah dokumen. Selanjutnya area 
utama kajian Dokumentasi adalah: 1) Dokumentasi sebagai proses; 2) Dokumentasi sebagai produk (dokumen) dan 3) Dokumentasi sebagai ilmu.

d. Ilmu dokumentasi berkembang dan mencakup berbagai aspek yang sangat luas. Posisi dalam lingkungan budaya dan kemanusiaan adalah ideal karena kemelekatan yang kuat antara dokumentasi dengan hidup keseharian hidup umat manusia.

e. Studi ilmu dokumentasi perlu juga dibangkitan kembali dan dikembangkan juga di Indonesia. Pengembangan ini dapat mulai dari pengkajian proses dan produk tersebut terdahulu. Pengkajian itu harus dilakukan secara akademik. Artinya praktik kaum dokumentalis perlu dikaji oleh para akademisi ataupun para pihak pemerhati masalah dokumentasi secara akademik.

f. Hasil kajian tersebut hendaknya dapat ditindaklanjuti menjadi kolokium ilmiah antara para akademisi dan kaum praktisi. Suatu interaksi yang berkesinambungan seharusnya dilakukan.

g. Pengkajian atau penelitian praktik dan fenomena dokumentasi bukanlah monopoli para akademisi. Kini kaum praktisi semakin punya kesempatan melakukan penelitian. Namun semua itu terpulang pada kebijakan lembaga tempat kaum praktisi bekerja.

Uraian tentang Logika Dokumentasi di atas dapat dirangkum dalam beberapa butir berikut:

a. Dokumentasi pada dasarnya merupakan proses siklus.

b. Objek nyata atau objek maya didokumentasikan menjadi objek nyata atau digital.

c. Objek ini didokumentasikan kembali (antara lain memakai TIK) menjadi objek maya baru

d. Demikian Proses ini berulang-ulang.

e. Dokumentasi adalah langkah penciptaan pengetahuan dan/atau ilmu pengetahuan.

f. Dokumentasi adalah kegiatan yang mengeksplisitkan pengetahuan tasit dan mengelola pengetahuan eksplisit.

g. Dokumentasi adalah simulasi kerja otak. 
h. Dokumentasi adalah fungsi yang harus dilakukan oleh semua orang.

i. Dokumentasi adalah objek, proses dan ILMU.

\section{PENUTUP}

Demikian luas dan cepat perkembangan ilmu dokumentasi di tataran internasional. Harus diakui bahwa ilmu dokumentasi belum (untuk tidak mengatakan TIDAK) berkembang di Indonesia. Dokumentasi dianggap hanya masalah teknis catat-mencatat atau rekam-merekam pada setiap bidang kegiatan. Dapat dikatakan bahwa dokumentasi yang diajarkan terbatas pada "bagaimana mengerjakan" atau "how to do" dan belum mempertanyakan "mengapa mengerjakan" atau "why to do". Jika posisi ilmu dokumentasi yang adalah studi tentang dokumen saya lukiskan dalam diagram berikut, muncul pertanyaan: “Apa, mengapa, dan bagaimana para akademisi dan praktisi menjawabnya?"

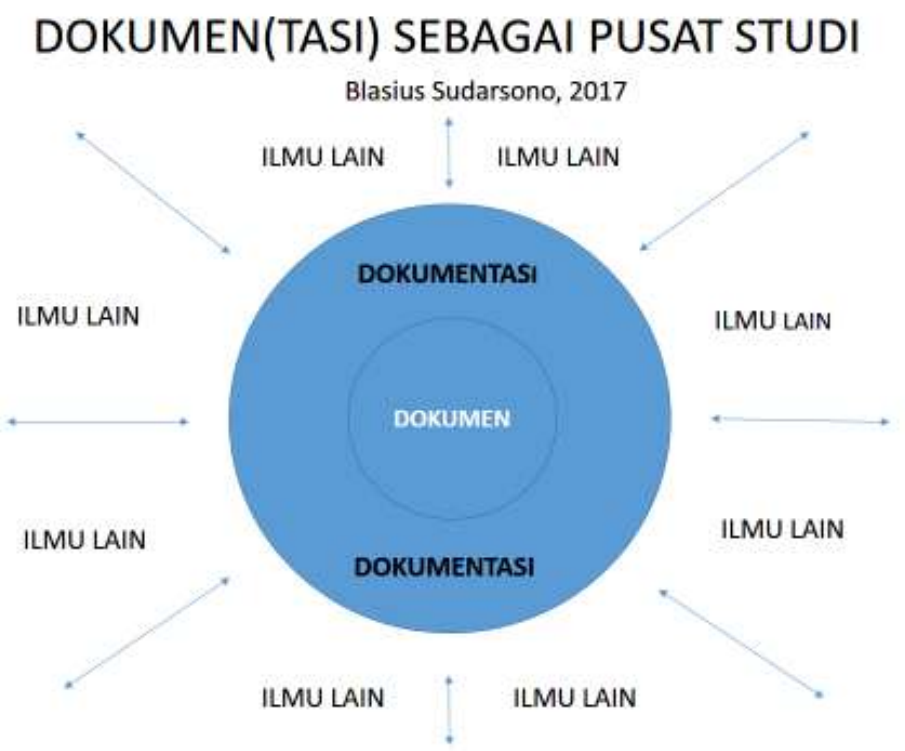

\section{DAFTAR PUSTAKA}

Buckland, M. K. (2013). Document Theory: An Introduction. Preprint, Nov 7, 2013, of presentation at the Summer School on Records, Archives and Memory Studies, University of Zadar, Department of Information Sciences, Zadar, Croatia, 6 to 10 May.

Buckland, M. K. and Niels W. Lund (2013). Boyd Rayward, Documentation, and Information Science. Library Trends, Vol. 62, No. 2, 2013. 
Ferraris, Maurizio. (2006). Documentality. New York, Italian Academy, October 11th 2006.

Ferraris, Maurizio. (2014).Total Mobilization. The Monist; Apr; 97, 2.

Lund, Niels Windfeld. (2003). Doceo + mentum - a ground for a new discipline. Paper to the DOCAM '03 conference, SIMS, UC-Berkeley, CA, Aug.1315.http://www.thedocumentacademy.org/resources/2003/papers/lund.pap er.ml

Lund, Niels Windfeld. (2004). Building a Discipline, Creating a Profession: An Essay on the Childhood of "Dokvit". http://munin.uit.no/bitstream/handle/10037/966/paper.pdf?sequence=1

Lund, W. N. (2010). Document, Text and Medium: Concepts, Theories and Disciplines. Journal of Documentation Vol. 66 No. 5, pp. 734-749

Presiden Republik Indonesia (1961). Peraturan Presiden Republik Indonesia Nomor 20 tentang Tugas-Kewajiban dan Lapangan Pekerjaan Dokumentasi dan Perpustakaan dalam Lingkungan Pemerintah.

Rayward, Warden Boyd (2012). Paul Otlet, an encounter. Cahiers de la documentation - Bladen voor documentatie - 2012/2, pp 71-73.

Sudarsono, Blasius (2016). Menuju Era Baru Dokumentasi. Jakarta: LIPI Press. 